\title{
EFEKTIVITAS ANTIINFLAMASI FRAKSI AIR EKSTRAK DAUN SEMBUKAN (Paederia foetida L.) PADA TIKUS PUTIH (Rattus Norvegicus)
}

\author{
Rio Saddam Pratama*, Aditya Fridayanti, Arsyik Ibrahim \\ Laboratorium FARMAKA TROPIS, Fakultas Farmasi, Universitas Mulawarman, Samarinda, Kalimantan Timur \\ *email: rankyaku@ rocketmail.com
}

\begin{abstract}
ABSTRAK
Telah dilakukan penelitian Aktivitas Antiinflamasi Ekstrak Daun Sembukan (Paederia foetida L.) Pada Tikus Putih (Rattus Norvegiens). Penelitian ini bertujuan untuk mengetahui berapa dosis efektif dari fraksi ekstrak daun sembukan yang paling baik memberikan efek antiinflamasi terhadap edema buatan pada telapak kaki tikus putih. Penelitian menggunakan metode pembentukan edema buatan dan mengukur volume kaki tikus putih secara berkala dengan menggunakan alat pletismometer. Dosis yang digunakan untuk ekstrak adalah $25 \mathrm{mg} / 200 \mathrm{gBB}, 50 \mathrm{mg} / 200 \mathrm{gBB}$, dan $100 \mathrm{mg} / 200 \mathrm{gBB}$. Data hasil penelitian selanjutnya diolah dengan menggunakan analisis varian (Anava) dua arah, pengujian lanjutan uji BNJD (Beda Nyata Jujur Duncan). Hasil penelitian yang menyatakan dosis efektif ekstrak daun sembukan yaitu dosis $50 \mathrm{mg} / 200 \mathrm{gBB}$ yang memiliki aktivitas antiinflamasi paling baik.
\end{abstract}

Kata Kunci : Ekstrak Daun Sembukan (Paederia foetida L.), Aktivitas Antiinflamasi, Tikus Putih (Rattus norvegicus)

\section{PENDAHULUAN}

Herba merupakan penghasil senyawa metabolit sekunder yang penting bagi kesehatan dan bahan obat-obatan. Dewasa ini kebutuhan obat tradisional terus meningkat.dinegara berkembang konsumsi masyarakat terhadap obat tradisional mencapai $80 \%$ dari jumlah populasinya. Masih banyak jenis tumbuhan yang belum diketahui potensi kegunaannya. Di Indonesia terdapat sekitar 2.518 jenis tumbuhan yang berkhasiat obat dan kesehatan. Jumlah ini akan terus bertambah seiring dengan ditemukannya jenis-jenis tumbuhan baru yang berkhasiat obat. Tumbuhan dapat sebagai sumber bahan kimia produk alami bahan obat yang penting bagi kesehatan dan kesejatheraan manusia (Solikin, 2007). Beberapa jenis tumbuhan herba liar telah digunakan sebagai bahan pengobatan tradisional, seperti tumbuhan sembukan (Paederia foetida L.).

Tumbuhan sembukan (Paederia foetida $L$.) adalah salah satu tanaman yang belum dimanfaatkan secara optimal. Nama tanaman ini mungkin sudah banyan didengar orang tetapi masih belum banyak diketahui manfaatnya. Paederia foetida $L$. yang sering dikenal sebagai sembukan atau daun kentut memiliki berbagai macam khasiat dan kegunaan. Tanaman ini dapat berfungsi sebagai antirematik, penghilang rasa sakit atau analgesik, peluruh kentut, peluruh kencing (diuretik), peluruh dahak (mukolitik), penambah nafsu makan, antibiotik, antiradang, obat batuk dan pereda kejang. Selain itu juga dapat berperan sebagai obat radang usus, bronkitis, tulang patah, keseleo, perut kembung, hepatitis, disentri, luka benturan, dan obat cacing (Utami, 2008), 
mengatasi demam, masuk angin, rematik, herpes, disentri (Solikin, 2007).

Kandungan yang terdapat dalam tanaman ini cukup banyak antara lain pada tangkai dan daun sembukan mengandung asperuloside, deacetylas peruloside, scandoside, paederoside, paederosidic acid dan alkaloids gamma-sitosterol, arbutin, oleanolic acid, irodoid, serta minyak menguap. Sembukan (Paederia foetida L.) merupakan salah satu anggota suku rubiacea (Dalimartha, 2009).

Salah satu teknik yang paling umum digunakan berdasarkan kemampuan agen tersebut untuk menghambat produksi edema di kaki belakang tikus setelah injeksi agen radang yang kemudian diukur volume radang. Volume edema diukur sebelum dan sesudah pemberian zat yang diuji. Beberapa iritan yang dipakai sebagai penginduksi edema antara lain formalin, kaolin, ragi, dan dekstran. Iritan yang umum digunakan dan memiliki kepekaan yang tinggi adalah karagen (Vogel, 2002).

Penelitian in vivo mengenai efek antiinflamasi daun sembukan sudah dilakukan, penelitian efek antiinflamasi daun sembukan dengan menitik beratkan pada pengamatan volume edema sebelumnya dilakukan pada ekstrak etanol dan mendapatkan dosis efektif $20 \mathrm{mg} / \mathrm{KgBB}$, sehingga timbul permasalahan bagaimana efek antiinflamasi pada fraksi ekstrak daun sembukan dan berapa dosis efektif dari fraksi yang paling baik memiliki efek antiinflamasi terhadap edema buatan pada kaki tikus putih jantan (Rattus norvegicus). Hasil penelitian ini diharapkan mampu memberikan informasi mengenai tumbuhan sembukan sebagai obat antiinflamasi alami yang berasal dari alam.

\section{METODE PENELITIAN}

\section{Bahan}

Daun sembukan (Paederia foetida L.), pelarut metanol (96\%), air suling, natrium CMC, karagenan.

\begin{abstract}
Alat
Pletismometer, timbangan hewan, spoid oral, spoid injeksi, peralatan gelas, labu takar, batang pengaduk, penangas air, cawan porselen, dan inkubator.
\end{abstract}

\section{Prosedur Penelitian}

Sebelum pengujian, tikus dipuasakan selama 18 jam dengan tetap diberi air minum. Tikus putih yang digunakan sebanyak 12 ekor yang telah dibagi menjadi tiga kelompok, masing-masing kelompok terdiri dari 4 ekor tikus putih. Kelompok pertama sebagai kontrol negatif hanya diberikan suspensi Na.CMC $1 \%$ dalam air suling secara oral. Kelompok kedua sampai keempat merupakan kelompok uji diberi fraksi air ekstrak daun sembukan dengan variasi dosis berbeda yaitu $25 \mathrm{mg} / 200 \mathrm{gBB}, 50 \mathrm{mg} / 200 \mathrm{gBB}$, dan $100 \mathrm{mg} / 200 \mathrm{gBB}$ yang diberikan secara oral.

Masing-masing hewan ditimbang dan diberi tanda pada kaki kirinya, Volume kaki tikus diukur dengan menggunakan pletismometer. Hasil pengukuran telapak kaki ini merupakan nilai volume awal $\left(\mathrm{V}_{0}\right)$ yaitu volume kaki tikus sebelum diinduksi menggunakan karagenan. Selanjutnya masing-masing tikus diberi suspensi ekstrak uji secara oral sesuai dengan kelompok uji. Satu jam kemudian, masingmasing telapak kaki tikus disuntik secara subkutan intraplantar dengan $0,1 \mathrm{~mL}$ 
larutan karagenan $1 \%$. Tiga puluh menit kemudian dilakukan lagi pengukuran volume kaki tikus, perubahan volume telapak kaki tikus yang terjadi dicatat sebagai volume kaki tikus waktu ke-t $\left(\mathrm{V}_{\mathrm{t}}\right)$. Pengukuran dilakukan setiap 30 menit. Volume radang adalah selisih volume kaki tikus setelah dan sebelum disuntikkan karagenan.

\section{HASIL DAN PEMBAHASAN}

Pengujian aktivitas antiinflamasi ekstrak daun sembukan merupakan suatu pengujian untuk mengetahui kemampuan ekstrak dalam menghambat dan mempercepat penyembuhan peradangan dengan cara melihat penurunan pembengkakan pada kaki tikus putih dengan mengukur volume kaki tikus menggunakan pletismometer setiap 30 menit hingga kaki kembali normal. Dari hasil penelitian dengan mengukur kaki tikus menggunakan pletismometer dapat disimpulkan bahwa variasi dosis ekstrak daun sembukan dapat mempercepat penurunan radang pada kaki tikus putih.

Metode pembentukan radang buatan merupakan salah satu metode pengujian aktivitas antiinflamasi berdasarkan kemampuan agen tersebut untuk menghambat produksi radang di kaki tikus setelah injeksi agen radang yang kemudian diukur volume radang. Volume radang diukur sebelum dan sesudah pemberian zat yang diuji. Beberapa iritan yang dipakai sebagai penginduksi radang antara lain formalin, kaolin, ragi, dekstran, dan karagenan. Karagenan adalah sulfat polisakarida bermolekul besar sebagai induktor inflamasi. Penggunaan karagenan sebagai penginduksi radang memiliki beberapa keuntungan antara lain: tidak meninggalkan bekas, tidak menimbulkan kerusakan jaringan dan memberikan respon yang lebih peka terhadap obat antiinflamasi dibanding senyawa iritan lainnya (Rowe et al, 2003). Hasil dari penelitian dapat dilihat secara visual.

Data hasil pengujian pendahuluan dijadikan acuan untuk menentukan dosis uji. Pengujian dilakukan dengan membagi 12 ekor tikus putih menjadi 4 kelompok. Masing-masing kelompok terdiri atas 3 ekor tikus putih. Kelompok pertama sebagai kontrol negatif, diikuti dengan kelompok kedua sampai keempat merupakan kelompok uji fraksi air ekstrak daun sembukan yaitu kelompok kedua dengan menggunakan dosis $25 \mathrm{mg} / 200 \mathrm{gBB}$, kelompok ketiga dengan menggunakan dosis $50 \mathrm{mg} / 200 \mathrm{gBB}$ dan kelompok keempat dengan menggunakan dosis 100mg/200gBB. Data hasil penelitian dapat dilihat pada Gambar 1 dan Tabel 1.

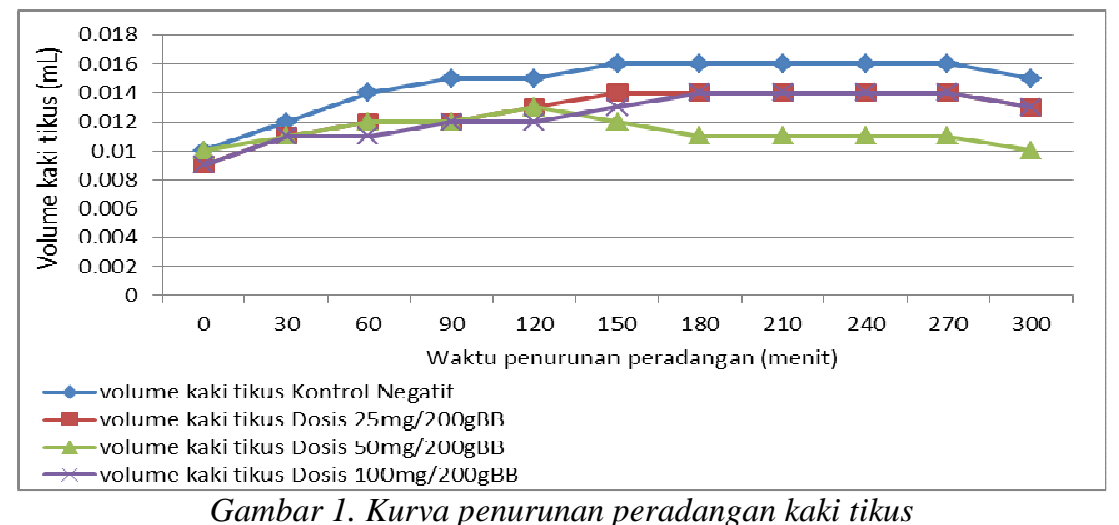

Gambar 1. Kurva penurunan peradangan kaki tikus 
Tabel 1.Hasil pengujian aktivitas antiinflamasi

\begin{tabular}{ccccc}
\hline \multirow{2}{*}{$\begin{array}{c}\text { Waktu } \\
\text { (menit) }\end{array}$} & \multicolumn{4}{c}{ Volume kaki tikus dosis uji $(\mathrm{mL}) \pm \mathrm{SD}$} \\
\cline { 2 - 4 } & Kontrol Negatif & Dosis $25 \mathrm{mg} / 200 \mathrm{gBB}$ & Dosis $50 \mathrm{mg} / 200 \mathrm{gBB}$ & Dosis $100 \mathrm{mg} / 200 \mathrm{gBB}$ \\
\hline 0 & $0,01 \pm 0,0015$ & $0,009 \pm 0,0005$ & $0,01 \pm 0,0011$ & $0,009 \pm 0,0005$ \\
30 & $0,012 \pm 0,0020$ & $0,011 \pm 0,0005$ & $0,011 \pm 0,0010$ & $0,011 \pm 0,0015$ \\
60 & $0,014 \pm 0,0017$ & $0,012 \pm 0,0005$ & $0,012 \pm 0,0011$ & $0,011 \pm 0,0011$ \\
90 & $0,015 \pm 0,0017$ & $0,012 \pm 0,0005$ & $0,012 \pm 0,0011$ & $0,012 \pm 0,0005$ \\
120 & $0,015 \pm 0,0010$ & $0,013 \pm 0,0000$ & $0,013 \pm 0,0011$ & $0,012 \pm 0,0005$ \\
150 & $0,016 \pm 0,0005$ & $0,014 \pm 0,0010$ & $0,012 \pm 0,0005$ & $0,013 \pm 0,0005$ \\
180 & $0,016 \pm 0,0005$ & $0,014 \pm 0,0010$ & $0,011 \pm 0,0011$ & $0,014 \pm 0,0005$ \\
210 & $0,016 \pm 0,0011$ & $0,014 \pm 0,0005$ & $0,011 \pm 0,0011$ & $0,014 \pm 0,0005$ \\
240 & $0,016 \pm 0,0015$ & $0,014 \pm 0,0017$ & $0,011 \pm 0,0010$ & $0,014 \pm 0,0005$ \\
270 & $0,016 \pm 0,0010$ & $0,014 \pm 0,0017$ & $0,011 \pm 0,0010$ & $0,014 \pm 0,0010$ \\
300 & $0,015 \pm 0,0015$ & $0,013 \pm 0,0010$ & $0,01 \pm 0,0011$ & $0,013 \pm 0,0005$ \\
\hline
\end{tabular}

Berdasarkan data dari tabel dan kurva diatas dapat dilihat aktivitas antiinflamasi yang dihasilkan kelompok uji dengan perbedaan kecepatan penurunan peradangan jika dibandingkan dengan kontrol negatif. Dari tabel dan kurva diatas dapat dilihat pula perbedaan kecepatan penurunan diantara kelompok uji dimana pada kelompok ketiga atau pada dosis $50 \mathrm{mg} / 200 \mathrm{gBB}$ menunjukkan penurunan yang signifikan pada menit ke-150 dimana pada kelompok kedua atau dosis $25 \mathrm{mg} / 200 \mathrm{gBB}$ dan kelompok keempat atau dosis $100 \mathrm{mg} / 200 \mathrm{gBB}$ masih mengalami kenaikan peradangan dan baru mulai menunjukkan adanya aktivitas penurunan pada menit ke-300.

Dosis efektif fraksi air ekstrak daun sembukan terhadap penurunan radang tiap kelompok diketahui dengan melakukan dianalisis secara statistik dengan metode anava 2 arah pada tingkat kepercayaan 95\% dan 99\%. Dari hasil analisa statistik menunjukkan bahwa $\mathrm{F}$ hitung dosis 6,00 > 3,12 (taraf 0,05), 6,00> 4,92 (taraf 0,01) lebih besar daripada $\mathrm{F}$ tabel, sedangkan $\mathrm{F}$ hitung waktu 1,08 $<2,01$ (taraf 0,05), 1,08 $<2,67$ (taraf 0,01) lebih kecil daripada $\mathrm{F}$ tabel. Hal ini berarti terdapat perbedaan bermakna aktivitas antiinflamasi atau dengan kata lain terdapat pengaruh antar dosis namun tidak terdapat pengaruh antar waktu pemberian pada pemberian fraksi air ekstrak daun sembukan terhadap radang pada kaki tikus putih.

Kelompok dosis pemberian yang mempunyai pengaruh antar dosis, dapat diketahui dengan uji lanjutan yaitu Uji Beda Nyata Jujur Duncan (BNJD). Hasil uji BNJD menunjukkan bahwa dosis yang paling efektif dan baik dalam menurunkan peradangan dari ketiga dosis yang digunakan adalah dosis $50 \mathrm{mg} / 200 \mathrm{gBB}$, dimana mampu menurunkan secara bermakna pada taraf 5\% ( $\mathrm{p}>0,05)$ dan $1 \%(\mathrm{p}>0,01)$ bila dibandingkan dengan dosis $25 \mathrm{mg} / 200 \mathrm{gBB}$ dan $100 \mathrm{mg} / 200 \mathrm{~g} \mathrm{BB}$, kemudian untuk dosis $100 \mathrm{mg} / 200 \mathrm{gBB}$ memberikan penurunan sebanding dengan dosis $25 \mathrm{mg} / 200 \mathrm{~g}$ BB pada taraf $5 \%$ ( $<$ $0,05)$ dan $1 \%(\mathrm{p}<0,01)$.

\section{KESIMPULAN}

Dosis efektif ekstrak daun sembukan yang memiliki aktivitas antiinflamasi adalah $50 \mathrm{mg} / 200 \mathrm{gBB}$. 


\section{DAFTAR PUSTAKA}

1. Rowe, C. R.; Sheskey, J. P.; \& Weller, J.W. 2003. Handbook of Pharmaceutical Excipien, 4th edition, 101-103, Pharmaceutical Press and American Pharmaceu.

2. Setiawan Dalimartha, 2009. Atlas Tumbuhan Obat Indonesia Jilid 6, Pustaka Bunda; Jakarta.
3. Solikin, 2007. Potensi Jenis-jenis Herba Liar Kebun Raya Purwodadi sebagai Obat, Http://fisika.brawijaya.ac.id/bssub/pro cceding/PDF\%20FILES/BSS_118_2. pdf, diakses pada 17 februari 2013.

4. Utami, P. 2008. Buku Pintar tanaman Obat, Agromedia; Jakarta.

5. Vogel, H.G. 2002. Drug Discovery and Evaluation, Pharmacological Assay; Berlin. 